\title{
DETERMINAN PENGANGGURAN LULUSAN PERGURUAN TINGGI DI INDONESIA TAHUN 2018
}

\author{
Vina Astriani ${ }^{1}$ \\ Program Studi D-IV Statistika, Politeknik Statistika STIS. Email : 211710040@stis.ac.id \\ Rani Nooraeni ${ }^{2}$ \\ Program Studi D-IV Statistika, Politeknik Statistika STIS. E-mail : raninoor@stis.ac.id
}

\begin{abstract}
Abstrak
Pengangguran merupakan salah satu permasalahan kompleks yang dihadapi oleh setiap negara berkembang di dunia, termasuk Indonesia. Berdasarkan data resmi Badan Pusat Statistik (BPS), jumlah pengangguran di Indonesia sejak tahun 2015 sampai dengan tahun 2018 tidak pernah bernilai lebih sedikit dari 7 juta orang, di mana jumlah Tingkat Pengangguran Terbuka (TPT) lulusan perguruan tinggi masih termasuk tinggi. Penelitian ini bertujuan untuk mengetahui faktor-faktor yang memengaruhi pengangguran lulusan perguruan tinggi di Indonesia tahun 2018 dengan menggunakan analisis regresi logistik biner. Adapun determinan pengangguran lulusan perguruan tinggi adalah umur, status kawin dan status KRT berpengaruh signifikan dan negatif terhadap pengangguran lulusan perguruan tinggi. Sedangkan, jenis kelamin dan sektor pekerjaan berpengaruh signifikan dan positif terhadap pengangguran lulusan perguruan tinggi.
\end{abstract}

Kata Kunci: Pengangguran, Lulusan perguruan tinggi, Regresi Logistik Biner.

\begin{abstract}
Unemployment is one of the complex problems faced by every developing country in the world, including Indonesia. Based on official data from Statistics Indonesia (BPS), the number of unemployed people in Indonesia from 2015 to 2018 was never worth less than 7 million people, where the number of open unemployment rate (TPT) of college graduates is still high. This study aims to determine the factors that influence unemployment of tertiary education graduates in Indonesia in 2018 by using binary logistic regression analysis. The determinants of unemployment for college graduates are age, marital status and KRT status have a significant and negative effect on unemployment of college graduates. Meanwhile, gender and employment sector have a significant and positive effect on unemployment of college graduates.
\end{abstract}

Keywords: Unemployment, College Graduates, Binary Logit Regression.

\section{PENDAHULUAN}

Pengangguran merupakan salah satu permasalahan kompleks yang dihadapi oleh setiap negara berkembang di dunia, tidak terkecuali Indonesia. Pengangguran merupakan masalah yang sangat sulit dihindari sehingga memiliki urgensi yang tinggi untuk ditangani mengingat dapat menimbulkan masalah sosial seperti tindakan kriminalitas dan masalah ekonomi. Terlebih di era revolusi industri $4.0 \mathrm{ini}$, di mana penggunaan teknologi yang menggantikan tenaga kerja manusia akan memberikan dampak buruk di bidang ketenagakerjaan. Revolusi yang berbasis digital mengancam eksistensi sejumlah pekerjaan akibat berkurangnya perusahaan yang merupakan dampak otomatisasi dan digitalisasi seperti yang ditunjukkan oleh hasil penelitian dari Mckinsey Global Institute di 46 negara pada tahun 2017. Menurut
Kalsum (2017), tingkat pengangguran di suatu daerah juga berpengaruh terhadap tingkat kesejahteraan dan daya beli masyarakat di mana semakin rendah angka pengangguran maka semakin makmur kehidupan masyarakat suatu negara, begitu pula sebaliknya. Berkaca dari fakta tersebut, tidak mengherankan jika menurunkan jumlah pengangguran merupakan salah satu tujuan dari seluruh negara di dunia.

Pada akhir tahun 2015, sidang umum Perserikatan Bangsa-Bangsa (PBB) berhasil mencanangkan program rencana aksi global pembangunan berkelanjutan atau Sustainable Development Goals (SDGs). Salah satu persoalan yang dibahas adalah mengurangi jumlah pengangguran di setiap negara di mana hal tersebut tertuang dalam tujuan 8 yang berbunyi "meningkatkan pertumbuhan ekonomi yang inklusif dan berkelanjutan, 
kesempatan kerja yang produktif dan menyeluruh, serta pekerjaan yang layak untuk semua". Tujuan ini tentunya akan menjadi salah satu acuan yang digunakan sebagai dasar dalam merealisasikan pembangunan yang berkelanjutan di seluruh negara di dunia, tidak terkecuali di Indonesia.

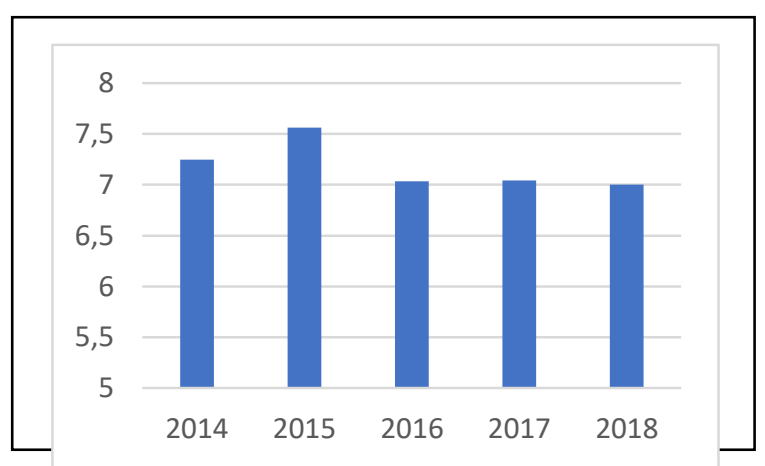

Sumber: Badan Pusat Statistık, diolah

Gambar 1. Jumlah Pengangguran d Indonesia Periode

Agustus 2015-2018 (dalam juta jiwa)

Berdasarkan data resmi Badan Pusat Statistik (BPS), jumlah pengangguran di Indonesia sejak tahun 2015 sampai dengan tahun 2018 tidak pernah bernilai lebih sedikit dari 7 juta orang, sebagaimana yang dapat dilihat pada Gambar 1. Dilihat dari Tingkat Pengangguran Terbuka (TPT), berdasarkan data dari Trading Economics dengan TPT sebesar 5,34 persen, Indonesia masih berada di urutan ketiga terbanyak di antara negara-negara ASEAN di bawah Brunei dan Filipina yang memiliki persentase tingkat pengangguran masing-masing sebesar 9,2 persen dan 5,4 persen. Hal tersebut mencerminkan bahwa permasalahan pengangguran memiliki urgensi yang tinggi untuk segera ditangani sehingga penting untuk mengetahui karakteristik dari pengangguran tebuka yang ada.

Dilihat dari karakteristik pendidikan tertinggi yang ditamatkan, pengangguran terbuka dibedakan menjadi enam kategori, yaitu kurang dari sama dengan SD, SMP, SMA, SMK, Diploma I/II/III, dan Universitas. Adapun persentase pengelompokan berdasarkan tingkat pensisikan tertinggi yang ditamatkan dapat dilihat pada Gambar 2.

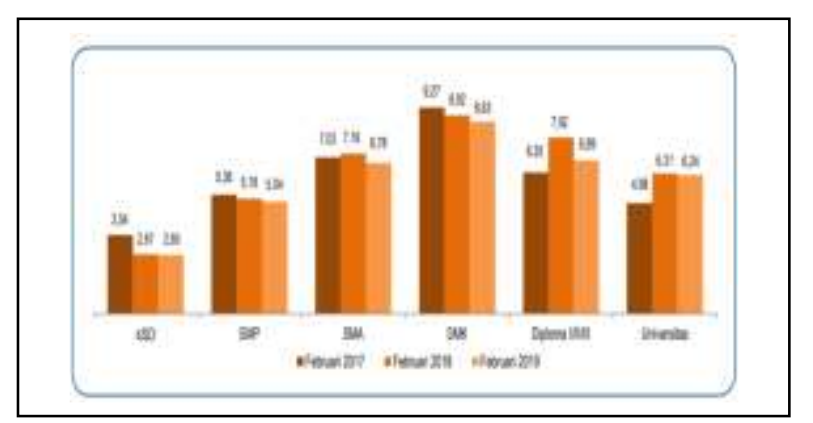

Sumber: Berita Resmi Statistik BPS Edisi 6 Mei 2019
Gambar 2. Tingkat Pengangguran Terbuka (TPT) Menurut Tingkat Pendidikan

Berdasarkan Gambar 2 dapat diinterpretasikan bahwa pada tahun 2018, lulusan diploma menduduki peringkat kedua pada tingkat pengangguran terbuka dengan persentase 7,92. Selain itu, dapat dilihat bahwa lulusan universitas yang termasuk ke dalam tingkat pengangguran terbuka pada tiga tahun terakhir bahkan bernilai lebih tinggi dibandingkan dengan lulusan maksimal sekolah dasar. Data tersebut mencerminkan bahwa lulusan diploma dan sarjana di Indonesia belum tentu mendapatkan pekerjaan.

Menilik dari fakta tersebut, terlihat bahwa lulusan diploma dan sarjana yang iharapkan mampu mengurangi angka pengangguran di Indonesia nyatanya justru turut menyumbangkan pengangguran. Berdasarkan penelitian yang dilakukan oleh Faga Arta Urtalina dan I Ketut Sudibia (2019), tingginya tingkat pengangguran terbuka lulusan diploma dan sarjana disebabkan karena kurang selarasnya antara perencanaan pendidikan dan juga lapangan pekerjaan yang tersedia. Ditambah lagi dengan fakta bahwa semakin tinggi tingkat pendidikan yang dimiliki oleh tenaga kerja akan semakin tinggi pula motivasinya untuk mendapatkan kedudukan atau kesempatan kerja yang lebih sesuai sehingga cenderung lebih selektif dalam memilih pekerjaan.

Berkaca dari ketidaksesuaian dari ekspektasi dan realitas yang terjadi di lapangan tersebut, dapat dikatakan upaya penanganan pemerintah yang hadir dalam berbagai bentuk kebijakan tersebut belum mampu merealisasikan peningkatan kualitas pendidikan dan penurunan jumlah pengangguran. Menilik dari data di atas, dapat dilihat bahwa lulusan perguruan tinggi yang notabene paling memiliki kompetensi dibandingkan lulusan lainnya ternyata masih cukup besar persentasenya dalam tingkat pengangguran terbuka. Padahal idealnya semakin tinggi tingkat pendidikan semakin besar pula peluang seseorang untuk mendapatkan pekerjaan karena kualifikasi yang dimilikinya. Dalam rangka pembuatan kebijakan yang tepat sasaran terhadap fenomena ini, penting untuk mengetahui terlebih dahulu apa saja faktor-faktor yang menyebabkan lulusan perguruan tinggi masih mnganggur. Berangkat dari permasalahan tersebut, kami tertarik untuk membuat penelitian yang berjudul "Determinan Pengangguran Lulusan Perguruan Tinggi di Indonesia Tahun 2018".

Oleh karena itu, penelitian ini dibuat untuk mengetahui faktor-faktor yang memengaruhi pengangguran lulusan perguruan tinggi di Indonesia tahun 2018.

\section{METODE}

Penelitian ini menggunakan analisis inferensia yang digunakan untuk melihat pengaruh variabel-variabel 
bebas terhadap variabel terikat. Analisis inferensia pada penelitian ini menggunakan analisis regresi logistik biner karena berguna untuk mengetahui pengaruh dan kecenderungan variabel-variabel bebas terhadap variabel terikat. Selain itu, analisis ini menggunakan aplikasi RStudio.

Variabel-variabel yang digunakan didapat dari data sekunder Survei Angkatan Kerja Nasional (SAKERNAS) BPS tahun 2018 dengan sampel yang diambil adalah individu dengan kategori angkatan kerja pada usia 15-64 tahun. Variabel terikat pada penelitian ini adalah pengangguran lulusan perguruan tinggi tahun 2018. Sedangkan variabel-variabel bebas pada penelitian ini adalah umur (X1), jenis kelamin (X2), status perkawinan (X3), status kepala rumah tangga (KRT) (X4), klasifikasi wilayah (X5), dan sektor pekerjaan berdasarkan pengalaman kerja (X6). Berikut rincian dari karakteristik variable independent dalam penelitian ini:

Tabel 1 Karakteristik Penduduk Lulusan Perguruan Tinggi

\begin{tabular}{|c|c|}
\hline Variabel & $\begin{array}{c}\text { Kategori (Dummy } \\
\text { Variable) }\end{array}$ \\
\hline $\operatorname{Umur}\left(\mathrm{X}_{1}\right)$ & - \\
\hline Jenis kelamin $\left(\mathrm{X}_{2}\right)$ & $\begin{array}{l}\text { Perempuan }(0)^{*} \\
\text { Laki-laki (1) }\end{array}$ \\
\hline Status kawin $\left(\mathrm{X}_{3}\right)$ & $\begin{array}{l}\text { Belum kawin }(0)^{*} \\
\text { Pernah kawin }(1)\end{array}$ \\
\hline Status KRT $\left(\mathrm{X}_{4}\right)$ & $\begin{array}{l}\text { Bukan KRT (0)* } \\
\text { KRT (1) }\end{array}$ \\
\hline Klasifikasi wilayah $\left(\mathrm{X}_{5}\right)$ & $\begin{array}{l}\text { Perdesaan }(0)^{*} \\
\text { Perkotaan }(1)\end{array}$ \\
\hline $\begin{array}{l}\text { Sektor pekerjaan yang memiliki } \\
\text { pengalaman kerja }\left(\mathrm{X}_{6}\right)\end{array}$ & $\begin{array}{l}\text { Bukan sektor formal } \\
(0)^{*} \\
\text { Sektor formal (1) }\end{array}$ \\
\hline $\begin{array}{l}\text { Pengangguran lulusan } \\
\text { perguruan tinggi }(Y)\end{array}$ & - \\
\hline
\end{tabular}

1. Model Regresi Logistik Biner

Regresi Logistik adalah model analisis statistik yang digunakan untuk melihat hubungan antara variabel terikat dengan dua atau lebih kategori dan variabel bebas kategorik atau kontinu. Regresi Logistik terbagi atas beberapa model, yaitu regresi logistik biner, regresi logistik multinomial dan regresi logistic ordinal.

Model Regresi Logistik Biner adalah model analisis statistik yang berguna untuk menganalisis hubungan antara variabel terikat yang memiliki dua kategori (dikotomi, 0 dan 1) dengan variabel bebas kategorik atau kontinu. Dalam penelitian ini, variabel terikat adalah kategorik (dikotomi) dengan nilai 1 menyatakan "pengangguran lulusan perguruan tinggi" dan nilai 0 menyatakan "pengangguran lulusan selain perguruan tinggi". Variabel terikat akan mengikuti distribusi Bernoulli dengan fungsi probabilitas sebagai berikut :

$$
f\left(y_{t}\right)=\pi\left(x_{i}\right)^{y_{i}}\left(1-\pi\left(x_{i}\right)\right)^{1-y_{i}}
$$

Keterangan :

$\pi\left(x_{i}\right) \quad$ : peluang kejadian ke-i

$y_{i} \quad:$ peubah acak ke-i, $y_{i}=0,1$

Model Regresi Logistik Biner adalah :

$$
\pi(x)=\frac{\exp \left(\alpha+\beta_{1} x\right)}{1+\exp \left(\alpha+\beta_{1} x\right)}
$$

Transformasi model regresi logistik biner menjadi bentuk logit regresi logistik :

$$
g(x)=\ln \left\lceil\frac{\pi(x)}{1-\pi(x)}\right\rceil=\alpha+\beta_{1} x
$$

Estimasi parameter pada analisis regresi logistik biner menggunakan metode Maximum Likelihood Estimation (MLE), namun metode tersebut belum menghasilkan estimator yang linier. Parameter diduga dengan memaksimumkan persamaan likelihood untuk mempermudah perhitungan, kemudian dilakukan pendekatan logaritma. Nilai dugaan dapat diperoleh dengan membuat turunan pertama dari fungsi logaritma terhadap yang hasilnya sama dengan 0 dengan $i=$ $1,2, \ldots, p$.

2. Uji Signifikansi

Uji signifikansi digunakan untuk menguji signifikansi dari parameter-parameter. Terdapat dua uji yang digunakan, yaitu Uji Rasio Likelihood dan Uji Wald.

- Uji Rasio Likelihood

Uji yang berfungsi untuk membandingkan model yang memuat variabel bebas dan model yang tidak memuat variabel bebas.

$\mathrm{H}_{0}: \beta_{0}=\beta_{1}=\cdots=\beta_{p}=0$

$\mathrm{H}_{1}$ : minimal $1 \beta_{j} \neq 0$ dengan $\mathrm{j}=1,2, \ldots, \mathrm{p}$

Statistik Uji :

$G=-2 \ln \left(\frac{\text { likelihood }(\text { Model B) }}{\text { likelihood }(\text { Model A) }}\right)$
Model B : Model tanpa variabel bebas (hanya konstanta)

Model A : Model dengan variabel bebas

Daerah Kritis : $G \sim \chi_{p}^{2}$

Keputusan : $G>\chi_{\alpha, p}^{2} \rightarrow$ Tolak Ho

Kesimpulan : Bila $\mathrm{H}_{0}$ ditolak, artinya model A signifikan pada taraf uji $\alpha$

\section{- Uji Wald}

Uji Wald berguna untuk mengetahui peranan masing-masing variabel bebas terhadap variabel terikat.

$\mathrm{H}_{0}: \beta_{j}=0$ dengan $\mathrm{j}=1,2, \ldots, \mathrm{p}$

$\mathrm{H}_{1}: \beta_{j} \neq 0$ dengan $\mathrm{j}=1,2, \ldots, \mathrm{p}$

Statistik Uji :

$W=\left[\frac{\hat{\beta}_{j}}{\operatorname{se}\left(\hat{\beta}_{j}\right)}\right]^{2} \sim \chi_{1}^{2}$

Keputusan : $W_{j}>\chi_{\alpha, 1}^{2} \rightarrow$ Tolak $\mathrm{H}_{0}$

Kesimpulan : Parameter yang diuji signifikan pada taraf uji $\alpha$.

3. Odds Ratio

Rasio kecenderungan (Odds Ratio) merupakan suatu ukuran berupa angka kecenderungan yang didefinisikan sebagai rasio antara jumlah individu yang mengalami 
kejadian tertentu dengan jumlah individu yang tidak mengalami kejadian, baik dalam sampel maupun populasi. Untuk peluang $\pi$ adalah berhasil, maka nilai odds rasio kecenderungan sebagai berikut :

$\Omega_{i}=\frac{\pi_{i}}{1-\pi_{i}}$

Rasio kemungkinan $\Omega_{1}$ dan $\Omega_{2}$ yang disebut odds rasio dapat ditulis sebagai berikut:

$$
\Psi=\frac{\Omega_{1}}{\Omega_{2}}=\frac{\frac{\pi_{1}}{1-\pi_{1}}}{\frac{\pi_{2}}{1-\pi_{2}}}
$$

Bila $\psi=1$, maka kedua variabel tidak terdapat hubungan. Bila $\psi<1$, maka kedua variabel terdapat hubungan negative terhadap perubahan kategori dari nilai $\mathrm{x}$. Begitu juga dengan $\psi>1$ (sebaliknya).

Bila $\psi=1$, maka kedua variabel tidak terdapat hubungan. Bila $\psi<1$, maka kedua variabel terdapat hubungan negative terhadap perubahan kategori dari nilai $\mathrm{x}$. Begitu juga dengan $\psi>1$ (sebaliknya).

\section{Goodness of Fit}

Terdapat beberapa pendekatan yang digunakan untuk menguji kesesuaian model, antara lain hasmer and lemeshow test, table klasifikasi dan kurva ROC.

- Hosmer and lemeshow test

Pada pengujian ini, hipotesis nol akan ditolak jika nilai $p$-value bernilai kurang dari $\alpha$. Model dinyatakan fit jika hasil ujinya adalah "Gagal Tolak $\mathrm{H}_{0}$ ".

- Kurva ROC

Kurva Receiver Operating Curve (ROC) menurut Hosmer and Lemeshow merupakan penjelasan mengenai akurasi ketepatan klasifikasi model berdasarkan luas area dibawah kurva ROC. Luas area di bawah kurva ROC memiliki rentang nilai antara 0 sampai 1 . Berdasarkan klasifikasi yang dijabarkan maka luas area dibawah kurva ROC dapat dikategorikan sebagai berikut :

1. $\mathrm{ROC}=0,5 \rightarrow$ tidak ada diskriminasi

2. $0,7 \leq \mathrm{ROC} \leq 0,8 \quad \rightarrow$ diskriminasi dapat diterima

3. $0,8 \leq \mathrm{ROC} \leq 0,9$

$\rightarrow$ diskriminasi baik

4. $\mathrm{ROC} \geq 0,9$

\section{HASIL DAN PEMBAHASAN}

\section{Model Regresi Logistik Biner}

Berdasarkan hasil penelitian ini, dengan memasukkan seluruh variabel yang dianggap memengaruhi pengangguran lulusan perguruan tinggi di Indonesia, didapatkan model persamaan regresi logistik biner sebagai berikut :

$$
\begin{aligned}
\hat{\mathrm{g}}(\mathrm{D})= & -3,02031^{*}-0,08937 \times 1 *+2,25970 \times 21^{*}- \\
& 1,84768 \times 31^{*}-1,00676 \times 41^{*}-0,11381 \times 51+ \\
& 0,45551 \times 61^{*}
\end{aligned}
$$

\section{Uji Signifikansi Parsial}

Dari hasil pengujian simultan dapat disimpulkan bahwa minimal terdapat satu variabel independen yang memengaruhi pengangguran lulusan perguruan tinggi di

Indonesia. Untuk dapat mengetahui variabel mana saja yang berpengaruh terhadap pengangguran lulusan

\begin{tabular}{|c|c|c|c|c|}
\hline $\begin{array}{l}\text { Dummy } \\
\text { Varible }\end{array}$ & Variabel & $\begin{array}{c}\text { Estima } \\
\text { te }\end{array}$ & $\begin{array}{c}\operatorname{Pr}(>|z| \\
)\end{array}$ & $\begin{array}{l}\text { Odds } \\
\text { Ratio }\end{array}$ \\
\hline (Intercept) & & $\begin{array}{c}- \\
3,0203 \\
1\end{array}$ & $\begin{array}{c}2,92 \mathrm{e}- \\
12\end{array}$ & $\begin{array}{c}0,0487 \\
85\end{array}$ \\
\hline $\mathrm{x} 1$ & Umur & $\begin{array}{c}- \\
0,0893 \\
7\end{array}$ & $\begin{array}{c}8,17 \mathrm{e}- \\
09\end{array}$ & $\begin{array}{c}0,9145 \\
03\end{array}$ \\
\hline $\mathrm{x} 21$ & $\begin{array}{l}\text { Jenis } \\
\text { kelamin } \\
(1)\end{array}$ & $\begin{array}{c}2,2597 \\
0\end{array}$ & $\begin{array}{c}<2 \mathrm{e}- \\
16\end{array}$ & $\begin{array}{c}9,5801 \\
74\end{array}$ \\
\hline $\mathrm{x} 31$ & $\begin{array}{l}\text { Status } \\
\text { kawin (1) }\end{array}$ & $\begin{array}{c}- \\
1,8476 \\
8\end{array}$ & $\begin{array}{c}8,88 \mathrm{e}- \\
14\end{array}$ & $\begin{array}{c}0,1576 \\
02\end{array}$ \\
\hline $\mathrm{x} 41$ & $\begin{array}{l}\text { Status } \\
\text { KRT (1) }\end{array}$ & $\begin{array}{c}- \\
1,0067 \\
6\end{array}$ & $\begin{array}{c}0,0023 \\
1\end{array}$ & $\begin{array}{c}0,3654 \\
02\end{array}$ \\
\hline $\mathrm{x} 51$ & $\begin{array}{l}\text { Klasifikas } \\
\text { i wilayah } \\
\text { (1) }\end{array}$ & $\begin{array}{c}- \\
0,1138 \\
1\end{array}$ & $\begin{array}{c}0,4214 \\
0\end{array}$ & $\begin{array}{c}0,8924 \\
23\end{array}$ \\
\hline x61 & $\begin{array}{l}\text { Sektor } \\
\text { pekerjaan } \\
\text { (1) }\end{array}$ & $\begin{array}{c}0,4555 \\
1\end{array}$ & $\begin{array}{c}0,0396 \\
6\end{array}$ & $\begin{array}{c}1,5769 \\
81\end{array}$ \\
\hline
\end{tabular}
perguruan tinggi, maka dapat dilanjutkan dengan uji parsial.

Tabel 2 Hasil Pengujian Parsial

Sumber: SAKERNAS Agustus 2018, diolah

$*)$ : Signifikan pada $\alpha=5 \%$

Dengan menggunakan tingkat signifikansi $\alpha$ sebesar 5\%, variabel independen dinyatakan berpengaruh terhadap variabel dependen ketika nilai $p$-value $<\alpha$. Berdasarkan Tabel 2 dapat diketahui bahwa klasifikasi wilayah tidak berpengaruh secara signifikan terhadap pengangguran lulusan perguruan tinggi di Indonesia.

Umur berpengaruh signifikan dan negatif terhadap pengangguran lulusan perguruan tinggi dan memiliki nilai odds ratio sebesar 0,9145 . Nilai ini dapat diartikan bahwa setiap penambahan umur 1 tahun maka kecenderungan untuk menjadi pengangguran lulusan perguruan tinggi akan bertambah 0,9145 kali. Hal ini sejalan dengan penelitian yang dilakukan oleh Wardhana Adhitya, et al (2019), dan Pasay dan Indrayanti (2012) yang menerangkan bahwa usia dapat mempengaruhi status pekerjaan karena fakta bahwa kelayakan kerja sejalan dengan pengalaman.

Jenis kelamin berpengaruh signifikan dan positif terhadap pengangguran lulusan perguruan tinggi. Nilai odds rationya adalah sebesar 9,5802 dengan perempuan sebagai kategori referensinya. Nilai ini dapat diartikan bahwa lulusan perguruan tinggi pada laki-laki cenderung untuk menjadi pengangguran 9,5802 kali lebih tinggi dibandingkan dengan lulusan perguruan tinggi pada perempuan. Hal tersebut diperjelas oleh penelitian yang dilakukan oleh Hartoko (2019) yang menyatakan bahwa lama waktu yang dibutuhkan laki-laki lebih panjang daripada perempuan, sehingga laki-laki cenderung untuk 
menganggur daripada perempuan. Selain itu, kecenderungan laki-laki untuk menganggur daripada perempuan juga disebabkan karena perempuan cenderung terlibat dalam pekerjaan dengan produktivitas yang rendah. Hal tersebut sesuai dengan pernyataan Kementerian Pemberdayaan Perempuan dan Perlindungan Anak (2016: 64). Namun, berbeda dengan penelitian yang dilakukan Aryati,F., et al. (2014) yang menyatakan bahwa angkatan kerja terdidik perempuan memiliki kecenderungan untuk menganggur dibandingkan laki-laki.

Status kawin berpengaruh signifikan dan negatif terhadap pengangguran lulusan perguruan tinggi. Nilai odds rationya adalah sebesar 0,1576 dengan belum kawin sebagai kategori referensinya. Nilai ini dapat diartikan bahwa lulusan perguruan tinggi yang berstatus kawin cenderung untuk menjadi pengangguran 0,1576 kali dibandingkan dengan lulusan perguruan tinggi yang belum kawin. Seseorang yang sudah menikah lebih mempertimbangkan tawaran suatu pekerjaan. Apabila lokasi pekerjaan jauh dari keluarga atau upah yang akan diterima kurang sesuai merupakan sebab seseorang menolak tawaran pekerjaan. Hal ini sesuai dengan penelitian Astuti (2013), status perkawinan yang sudah menikah membuat seseorang lebih sulit dalam mendapatkan pekerjaan sehingga masa menganggur menjadi lebih lama.

Status KRT berpengaruh signifikan dan negatif terhadap pengangguran lulusan perguruan tinggi. Nilai odds rationya adalah sebesar 0,3654 dengan bukan KRT sebagai kategori referensinya. Nilai ini dapat diartikan bahwa lulusan perguruan tinggi yang berstatus KRT cenderung untuk menjadi pengangguran 0,3654 kali lebih rendah dibandingkan dengan lulusan perguruan tinggi yang berstatus KRT.Status KRT mempengaruhi tingkat pengangguran. Seseorang yang menjadi menjadi kepala rumah tangga memiliki kecenderungan lebih kecil untuk menganggur. Hal ini juga sejalan dengan penelitian yang dilakukan oleh Berdasarkan penelitian yang dilakukan oleh Tasnim Khan dan Fatima Yousaf (2013) dengan judul "Unemployment Duration Of First Time Job Seekers: A Case Study Of Bahawalpur" didapatkan hasil bahwa status kepala rumah tangga memengaruhi tingkat pengangguran. Seseorang yang berstatus kepala rumah tangga memiliki kewajiban untuk menafkahi keluarganya. Menurut Harfina (2009), laki-laki dengan status sebagai kepala rumah tangga umumnya bekerja dengan jam kerja yang lebih penuh meskipun harus bekerja lebih dari dua jenis pekerjaan guna mencukupi dan memenuhi kebutuhan seluruh anggota rumah tangga. Tanggung jawab kepala rumah tangga akan kesejahteraan anggota rumah tangga memaksa mereka untuk tidak menganggur dan bekerja kurang dari 35 jam per minggu.

Sektor pekerjaan berpengaruh signifikan dan positif terhadap pengangguran lulusan perguruan tinggi. Nilai odds rationya sebesar 1,5770 dengan bukan sektor formal sebagai kategori referensinya. Nilai ini dapat diartikan bahwa lulusan perguruan tinggi yang bekerja di sektor formal cenderung untuk menjadi pengangguran 1,5770 kali lebih tinggi dibandingkan bekerja di sektor bukan formal. Selaras dengan penelitian yang dilakukan oleh Widyawati dan Tridiana (2019) menyatakan bahwa perbedaan pemberian upah minimum yang berbeda pada pekerja terampil dan non terampil memberikan hasil bahwa probabilitas keluar dari sektor formal akan lebih tinggi pada tenaga kerja tidak terampil dibandingkan tenaga kerja terampil.

\section{Uji Kesesuaian Model (Goodness of Fit) Hosmer and Lemeshow Test}

Tabel 3 Nilai Statistik Uji Hosmer and Lemeshow

\begin{tabular}{|l|l|l|}
\hline Chi-square & Df & Sig. \\
\hline 13,82 & 8 & 0,08659 \\
\hline
\end{tabular}

Kesimpulan : Hasil pada tabel menunjukkan bahwa nilai signifikansi lebih dari $\alpha=5$ persen. Maka dapat disimpulkan dengan tingkat signifikansi 5 persen, terdapat cukup bukti untuk menyatakan bahwa model yang digunakan cocok (fit) untuk digunakan pada penelitian ini.

Pengujian Hosmer dan Lemeshow disini menggunakan modifikasi Paul-Lemeshow (2012). Hal ini dikarenakan ukuran sampel dalam penelitian ini lebih dari 5000 sampel.

\section{Kurva ROC}

Selain menggunakan uji Hosmer dan Lemeshow, pada penelitian ini juga menguji kesesuaian model dengan menggunakan kurva ROC.

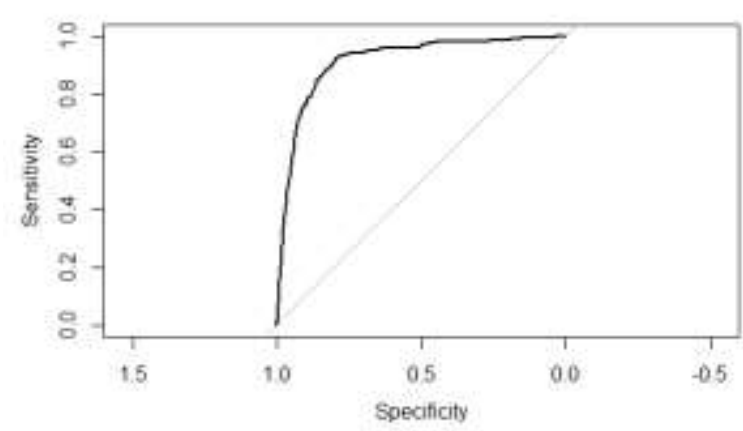

Gambar 2 Hasil Pengolahan Kurva ROC

Luas area di bawah kurva ROC sebesar 0,9149 dimana nilai tersebut mendekati 1. Selain itu, dapat dilihat pada Gambar 2 kurva berada jauh dari garis lurus yang menunjukkan bahwa luas area di bawah kurva ROC yang dihasilkan sudah presisi.

\section{PENUTUP}

\section{Simpulan}

Berdasarkan pembahasan yang telah dipaparkan di atas, didapatkan kesimpulan bahwa umur, status kawin dan status KRT berpengaruh signifikan dan negatif terhadap pengangguran lulusan perguruan tinggi. Sedangkan, jenis kelamin dan sektor pekerjaan 
berpengaruh signifikan dan positif terhadap pengangguran lulusan perguruan tinggi.

\section{Saran}

Berdasarkan penelitian ini maka saran yang dapat diberikan adalah meningkatkan mutu pendidikan perguruan tinggi di Indonesia untuk menghasilkan sumber daya manusia yang berkualitas. Selain itu, pengembangan jiwa kewirausahaan angkatan kerja lulusan perguruan tinggi dan pembuatan kebijakan yang mendukung dalam penyerapan tenaga kerja informal seperti program-program pengembangan usaha mikro, kecil, dan menengah (UMKM).

Bagi peneliti lain diharapkan dapat menambahkan variabel independen lainnya dan menggunakan metode analisis yang lebih kompleks untuk mendapatkan hasil penelitian yang menggambarkan kondisi sebenarnya.

\section{DAFTAR PUSTAKA}

Agresti, A. (2002). Categorical Data Analysis. United States: Wiley.

Aryati, F., Sunaryanto, H., \& Sunoto. (2014). Analisis Pengangguran Teridik di Provinsi Bengkulu. Jurnal Ekonomi dan Perencanaan Pembangunan, 70-79.

Astuti, M. (2013). Faktor-faktor Yang Mempengaruhi Lama Menganggur Bagi Pekerja di Industri Perkebunan Kelapa Sawit Ogan Komering Ulu. Jurna Ilmiah STIE MDP, 2(2), 130-149.

BPS. (2016). Potret Awal Tujuan Pembangunan Berkelanjutan di Indonesia. Jakarta: BPS.

BPS. (2019, Mei 6). Keadaan Ketenagakerjaan Indonesia Februari 2019. Berita Resmi Statistik.

BPS. (2019). Penduduk Berumur 15 Tahun ke Atas Menurut Jenis Kegiatan Tahun 1986-2019. Jakarta: BPS. Retrieved Januari 26, 2020, from https://www.bps.go.id/dynamictable/2020/02/19 /1775/penduduk-berumur-15-tahun-ke-atasmenurut-jenis-kegiatan-tahun-1986---2019.html.

Daruyani, S., Wulandari, Y., \& Yasin, H. (2013). Faktorfaktor Yang Mempengaruhi Indeks Prestasi Mahasiswa FSM Universitas Diponegoro Semester Pertama Dengan Metode Regresi Logistik Biner. Seminar Nasional Statistika (pp. 185-193). Semarang: Universitas Diponegoro.

Harfina, D. (2009). Faktor-faktor Yang Mempengaruhi Pengangguran Terselubung di Perdesaan Jawa Tengah. Jurnal Kependudukan Indonesia, 1(4), 15-32.
Hariandja, M. T. (2002). Manajemen Sumber Daya Manusia. Jakarta: Grasindo.

Hartoko, Y. (2019). Pengaruh Pendidikan, Pelatihan, Jenis Kelamin, Umur, Status Perkawinan, dan Daerah Tempat Tinggal terhadap Lama Mencari Tenaga Kerja Terdidik di Indonesia. Jurnal Pendidikan dan Ekonomi, 206.

Institute, M. G. (2017). Perekonomian Nusantara: Menggali Potensi Terpendam Indonesia. Jakarta: McKinsey and Company.

Kalsum, U. (2017). Pengaruh Pengangguran dan Inflasi terhadap Pertumbuhan Ekonomi di Sumatera Utara. Jurnal Ilmu Ekonomi dan Pembangunan, $1(17)$.

Kementerian Pemberdayaan Perempuan dan Perlindungan Anak. (2016). Statistik Gender Tematik - Potret Ketimpangan Gender dalam Ekonomi. Jakarta: Kementerian Pemberdayaan Perempuan dan Perlindungan Anak.

Khan, T., \& Yousaf , F. (2013). Unemployment Duration Of First Time Job Seekers: A Case Study Of Bahawalpur. Asian Journal of Economic Modelling, 1(1), 8-19.

Novianti, F. A., \& Purnami, S. W. (2012). Analisis Diagnosis Pasien Kanker Payudara Menggunakan Regresi Logistik dan Support Vector Machine (SVM) Berdasarkan Hasil Mamografi. Jurnal Sains dan Seni ITS, 1(1).

Pasay, N. H., \& Indrayanti, R. (2012). Pengangguran Lama Mencari Kerja. Jurnal Ekonomi dan Pembangunan, 12(2), 116-135.

Prabasaj , P., Pennel, L. M., \& Lemeshow, S. (2012). Standardizing the power of the HosmerLemeshow goodness of fit test in large data sets . Research Article Statistics in Medicine, 1-14.

Safitri, A., Sudarmin, \& Nusrang, M. (2017). Model Regresi Logistik Biner Pada Tingkat Pengangguran Terbuka di Provinsi Sulawesi Barat Tahun 2017. Journal of Statistics and Its Application on Teaching and Research.

Tampil, Y. A., Komalig, H., \& Langi, Y. (2017). Analisis Regresi Logistik Untuk Menentukan FaktorFaktor Yang. Jurnal Matematika dan Aplikasi, $6(2)$.

Tansel, A., \& Tasci, H. (2004). Determinants of Unemployment Duration for Men and Women in Turkey. Discussion Paper. 
Urtalina, A. F., \& Sudibia, I. K. (2018). Faktor-faktor yang Mempengaruhi Tingkat Pengangguran Terdidik Kabupaten/Kota di Bali. E-Jurnal EP Unud, 2190-2218.

Wardhana, A., Kharisma, B., \& Ibrahim, Y. F. (2019). Pengangguran Usia Muda di Jawa Barat. Jurnal Ekonomi dan Bisnis Universitas Udayana, 1049-1062.

Widyawati, D., \& Tridiana, C. (2019). Dampak Upah Minimum terhadap Probabilitas Keluar dari Sektor Formal. Jurnal Ekonomi dan Pembangunan Indonesia, 119-139. 